Biol. Stud. 2016: 10(2); 53-62 • DOI: https://doi.org/10.30970/sbi.1002.490

www.http://publications.Inu.edu.ua/journals/index.php/biology

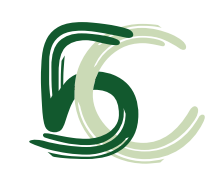

UDC 579.222:57.042

\title{
EFFECTS OF BICARBONATE AND ALPHA-KETOGLUTARATE ON SENSITIVITY OF SACCHAROMYCES CEREVISIAE YEAST TO HYDROGEN PEROXIDE AND IRON IONS
}

\author{
M. M. Bayliak \\ Vasyl Stefanyk Precarpathian National University \\ 57, Shevchenko St., Ivano-Frankivsk 76018, Ukraine \\ e-mail: bayliak@ukr.net
}

The effects of sodium bicarbonate on the sensitivity of Saccharomyces cerevisiae yeast to hydrogen peroxide and ferrous sulfate were studied. Viability of yeast cells treated with 10-25 $\mathrm{mM} \mathrm{H}_{2} \mathrm{O}_{2}$ and $0.1-0.2 \mathrm{mM} \mathrm{FeSO}_{4}$ was significantly decreased when 25 or $50 \mathrm{mM} \mathrm{NaHCO}_{3}$ was added to the medium. In the absence of bicarbonate, the levels of oxidative stress markers, namely protein carbonyls, total and oxidized glutathione in cells exposed to $0.2 \mathrm{mM} \mathrm{FeSO}_{4}$ did not differ from such levels in control cells (without $\mathrm{FeSO}_{4}$ ). Yeast cells incubated with $0.2 \mathrm{mM} \mathrm{FeSO}_{4}$ and $50 \mathrm{mM} \mathrm{NaHCO}_{3}$ had similar levels of oxidized glutathione and carbonyl groups in proteins but lower level of total glutathione compared to cells treated with $\mathrm{FeSO}_{4}$ in the absence of $\mathrm{NaHCO}_{3}$. Yeast cells exposed to a mixture of " $2 \mathrm{mM} \mathrm{H}_{2} \mathrm{O}_{2}+2 \mathrm{mM} \mathrm{FeSO}_{4}$ " in $50 \mathrm{mM}$ sodium bicarbonate buffer survived better than cells treated with these oxidants in $50 \mathrm{mM}$ potassium phosphate buffer. The addition of $10 \mathrm{mM}$ alpha-ketoglutarate led to the increased yeast survival in both buffers under the treatment with " $\mathrm{Fe}^{2+} / \mathrm{H}_{2} \mathrm{O}_{2}$ ". The protective effect of alphaketoglutarate can be due to its $\mathrm{H}_{2} \mathrm{O}_{2}$-scavenging activity. The results suggest that bicarbonate ions can enhance or alleviate the toxic effects of redox-active compounds on S. cerevisiae. Pro/antioxidant effects of bicarbonate ions are likely to depend on the kinetics of interaction between $\mathrm{HCO}_{3}{ }^{-}$and produced ROS.

Abbreviations: AKG (alpha-ketoglutarate); CP (carbonyl proteins); Cu, Zn-SOD (Cu, Zn-superoxide dismutase); KPi (potassium phosphate buffer); OD (optical density); ROS (reactive oxygen species).

Keywords: Saccharomyces cerevisiae, alpha-ketoglutarate, bicarbonate ions, carbonate radical, oxidative stress.

\section{INTRODUCTION}

Production of the reactive oxygen species (ROS) and carbon dioxide $\left(\mathrm{CO}_{2}\right)$ is a part of normal aerobic cellular metabolism $[19,26]$. ROS such as superoxide anion radical $\left(\mathrm{O}_{2}{ }^{-}\right)$, hydrogen peroxide $\left(\mathrm{H}_{2} \mathrm{O}_{2}\right)$, and hydroxyl radical $\left({ }^{\circ} \mathrm{OH}\right)$ are potentially dangerous

ISSN 1996-4536 (print) • ISSN 2311-0783 (on-line) • Біологічні Студії / Studia Biologica • 2016 • Том 10/№2 • С. 53-62 
due to their high reactivity and capability to interact with virtually all cellular components. Toxicity of ROS is largely dependent on the presence of ions of transition metals, such as iron and copper. Transition metals can participate in the formation of highly reactive hydroxyl radical in the Fenton reaction [24]: $\mathrm{Fe}^{2+}+\mathrm{H}_{2} \mathrm{O}_{2} \rightarrow \mathrm{Fe}^{3+}+{ }^{\circ} \mathrm{OH}+\mathrm{OH}^{-}$. Excessive ROS production and/or decrease in antioxidant defense leads to the development of oxidative stress, which is implicated in aging and many human diseases [19].

Carbon dioxide and its hydrated forms $\left(\mathrm{HCO}_{3}{ }^{-} \mathrm{i} \mathrm{CO}_{3}{ }^{2-}\right)$ are components of carbonate buffer system which plays an important role in $\mathrm{pH}$ regulation in biological liquids [23]. Bicarbonate buffer that is composed of $1.3 \mathrm{mM} \mathrm{CO}_{2}$ in equilibrium with $25 \mathrm{mM}$ $\mathrm{HCO}_{3}{ }^{-}$in serum and $14 \mathrm{mM} \mathrm{HCO}_{3}{ }^{-}$intracellularly, has well-demonstrated redox effects $[20,23]$. A number of studies demonstrated that $\mathrm{HCO}_{3}{ }^{-}$or $\mathrm{CO}_{2} / \mathrm{HCO}_{3}{ }^{-}$can stimulate the oxidation, peroxidation, and nitration of various molecules [1, 2, 5, 6, 10, 14, 28]. Carbon dioxide and (bi)carbonate ions enhance metal-catalyzed decomposition of $\mathrm{H}_{2} \mathrm{O}_{2}[5,14]$ and peroxidase activity of $\mathrm{Cu}, \mathrm{Zn}$-superoxide dismutase (Cu,Zn-SOD) $[9,15,28]$. At the same time, (bi)carbonate-mediated peroxidase activity of $\mathrm{Cu}, \mathrm{Zn}-\mathrm{SOD}$ leads to the formation of carbonate radical $\left(\mathrm{CO}_{3}{ }^{-}\right)$, which has strong oxidizing properties $[1,3,20,26$, 28]. $\mathrm{CO}_{3}{ }^{--}$formation was shown to be responsible for the increased oxidation of proteins and lipids in carbonate buffer under exposure to transition metals [2]. It should be noted that articles cited above and many similar articles used in vitro systems. There is a little information about similar processes in vivo. We have previously shown that bicarbonate buffer sensitized Saccharomyces cerevisiae yeast to menadione, a redox-active compound which is able to generate superoxide anion radical [17]. The inactivation of aconitase and the decrease in glutathione level in yeast cells treated with menadione in bicarbonate buffer were observed.

Taking into account that bicarbonate ions can intensify free radical processes, it seems possible that the exogenous antioxidant compounds can alleviate these processes. Recently, the antioxidant properties for alpha-ketoglutarate (AKG) as an important intermediate in the Krebs cycle were demonstrated. In particular, the ability to scavenge hydrogen peroxide was shown for AKG [4].

This study was aimed at studying the effects of sodium bicarbonate on sensitivity of yeast S. cerevisiae to hydrogen peroxide, iron ions and their mixture. The ability of AKG to prevent yeast cell death in bicarbonate buffer under combined treatment with $\mathrm{H}_{2} \mathrm{O}_{2}$ and $\mathrm{Fe}^{2+}$ was also studied.

\section{MATERIALS AND METHODS}

The S. cerevisiae strain YPH250 (MATa trp1- $\Delta 1$ his3- $\Delta 200$ lys2-801 leu2- $\Delta 1$ ade 2-101 ura3-52) was used in this study. The strain was kindly provided by Dr. Y. Inoue (Kyoto University, Japan). Cells were grown at $28^{\circ} \mathrm{C}$ with shaking at $175 \mathrm{rpm}$ in liquid medium containing $1 \%$ yeast extract, $2 \%$ peptone, $2 \%$ glucose (YPD). Exponentialphase cells were harvested after cultivation for $24 \mathrm{~h}\left(O D_{600}=1.4-1.5\right)$. In one series of experiments, cells were suspended in 100 mM HEPES buffer (pH 7.5)-contained $0.1 \%$ glucose and different concentrations of $\mathrm{NaHCO}_{3}$. The resulted cell suspensions were exposed to (i) 10-25 $\mathrm{mM} \mathrm{H}_{2} \mathrm{O}_{2}$ or (ii) 0.1-0.2 $\mathrm{mM} \mathrm{FeSO}_{4}$ for $2 \mathrm{~h}$. In other series of experiments, cells were suspended in $50 \mathrm{mM}$ potassium phosphate buffer $(\mathrm{KPi})(\mathrm{pH} 7.5)$ or in $50 \mathrm{mM}$ sodium bicarbonate buffer $(\mathrm{pH} 7.5)$ and then were exposed to: (i) $2 \mathrm{mM}$ $\mathrm{H}_{2} \mathrm{O}_{2}+2 \mathrm{mM} \mathrm{FeSO}_{4}$ or (ii) $2 \mathrm{mM} \mathrm{H}_{2} \mathrm{O}_{2}+2 \mathrm{mM} \mathrm{FeSO}_{4}+10 \mathrm{mM} \mathrm{AKG}$ for $1 \mathrm{~h}$. AKG was used in the form of disodium salt of alpha-ketoglutarate. The control cell suspensions

ISSN 1996-4536 (print) • ISSN 2311-0783 (on-line) • Біологічні Студії / Studia Biologica • 2016 • Том 10/№2 • С. 53-62 
were incubated under the same conditions without stressors. Cell survival after stress exposure was monitored by counting of colony-forming units on YPD agar plates.

Cell extracts were prepared by vortexing yeast cells with glass beads $(0.5 \mathrm{~mm})$, as described [17]. The content of carbonyl groups in the proteins (CP) was measured by determining the amount of 2,4-dinitrophenylhydrazone formed upon the reaction with 2,4-dinitrophenylhydrazine. Carbonyl content was calculated from the absorbance maximum of 2,4-dinitrophenylhydrazone at $370 \mathrm{~nm}$ with molar extinction coefficient of $22 \mathrm{mM}^{-1} \cdot \mathrm{cm}^{-1}$ [13]. The level of total glutathione was measured as described in the paper [18]. Yeast cells were suspended in $1.3 \%$ dinitrosalicilic acid and disrupted by vortexing with glass beads $(0.5 \mathrm{~mm})$ for three cycles $(1 \mathrm{~min}$ of disruption and $3 \mathrm{~min}$ of cooling on ice). For determination of oxidized glutathione, the aliquots of supernatants were incubated with $5 \%$ 2-vinylpyridine for $1 \mathrm{~h}$ at room temperature. Protein concentration was determined by Bradford [7] basing on binding of Coomassie brilliant blue G-250 dye with protein.

Experimental data are expressed as mean of 4-6 independent experiments \pm the standard error of the mean (SEM), and statistical analysis used Dunnett's test and Student's $t$-test [8].

\section{RESULTS AND DISCUSSION}

The survival of yeast cells upon treatment with hydrogen peroxide or ferrous sulfate in the presence of sodium bicarbonate at different concentrations was studied (Fig. 1). Hydrogen peroxide decreased yeast survival in both control and bicarbonate-supplemented suspensions (Fig. 1, A). The survival was decreased with increasing of $\mathrm{H}_{2} \mathrm{O}_{2}$ concentration. In particular, cell viability was 79 and $35 \%$ in the control suspensions treated with 10 and $25 \mathrm{mM} \mathrm{H}_{2} \mathrm{O}_{2}$, respectively. The addition of $10 \mathrm{mM} \mathrm{NaHCO}_{3}$ did not influence yeast resistance to $\mathrm{H}_{2} \mathrm{O}_{2}$, whereas $25 \mathrm{mM} \mathrm{NaHCO}_{3}$ enhanced sensitivity of yeast cells to $10 \mathrm{mM}$ and $15 \mathrm{mM} \mathrm{H}_{2} \mathrm{O}_{2}$. Yeast cells were the most sensitive to $\mathrm{H}_{2} \mathrm{O}_{2}$ in the presence of $50 \mathrm{mM} \mathrm{NaHCO}_{3}$ with 73 and $17 \%$ of survival after treatment with 10 and $25 \mathrm{mM} \mathrm{H}_{2} \mathrm{O}_{2}$, respectively.

The incubation of yeast cells with 0.1-0.2 $\mathrm{MM} \mathrm{FeSO}_{4}$ did not affect cell survival in the control (without bicarbonate) and in the medium, containing $10 \mathrm{mM} \mathrm{NaHCO}_{3}$ (Fig. 1, B). However, the treatment with ferrous sulfate in the presence of 25 or $50 \mathrm{mM} \mathrm{NaHCO}_{3}$ decreased yeast viability with more sensitizing effect of $50 \mathrm{mM} \mathrm{NaHCO}_{3}$. Thus, the survival decreased by 19 and $56 \%$ after treatment with $0.2 \mathrm{mM} \mathrm{FeSO}_{4}$ in the presence of 25 and $50 \mathrm{mM} \mathrm{NaHCO}_{3}$, respectively. The obtained results suggest that bicarbonate ions can enhance sensitivity of $S$. cerevisiae cells to hydrogen peroxide and iron ions.

Our results are consistent with previous reports in vitro which showed the ability of bicarbonate ions participate in redox-processes [3, 20, 23, 26]. In particular, the increase in peroxidase activity of $\mathrm{Cu}, \mathrm{Zn}-\mathrm{SOD}$ was shown in the presence of bicarbonate. The enzyme decomposes $\mathrm{H}_{2} \mathrm{O}_{2}$ with the formation of superoxide anion radical which is a direct substrate of SOD: SOD-Cu${ }^{2+}+\mathrm{H}_{2} \mathrm{O}_{2} \rightarrow$ SOD-Cu${ }^{1+}+\mathrm{O}_{2}^{--}+2 \mathrm{H}^{+}$; SOD-Cu ${ }^{1+}+$ $\mathrm{H}_{2} \mathrm{O}_{2} \rightarrow \mathrm{SOD}-\mathrm{Cu}^{2+}-{ }^{-} \mathrm{OH}+\mathrm{OH}^{-}$. At this process, the enzyme is converted to intermediate inactive form SOD-Cu${ }^{2+}-{ }^{-} \mathrm{OH}$ which can undergo further oxidative inactivation or can be restored to initial form (SOD- $\mathrm{Cu}^{2+}$ ) by interaction with (bi)carbonate ions. $\mathrm{HCO}_{3}{ }^{-}$and/or $\mathrm{CO}_{3}{ }^{2-}$ undergo one-electron oxidation to carbonate radical $\mathrm{CO}_{3}{ }^{--}$: SOD-Cu ${ }^{2+}-\mathrm{OH}+$ $\mathrm{HCO}_{3}{ }^{-} \rightarrow \mathrm{SOD}-\mathrm{Cu}^{2+}+\mathrm{H}_{2} \mathrm{O}+\mathrm{CO}_{3}{ }^{--}[9,15,20,26,28]$. It was also shown that in vitro $\mathrm{CO}_{3}{ }^{--}$ can be formed in the reaction of carbonate ions with peroxinitrite $\left(\mathrm{ONOO}^{-}\right)$or directly

ISSN 1996-4536 (print) • ISSN 2311-0783 (on-line) • Біологічні Студії / Studia Biologica • 2016 • Том 10/№2 • С. 53-62 
with hydroxyl radical $\left({ }^{\circ} \mathrm{OH}\right)[3,16,20]$. It was shown that the sensitivity of Escherichia coli bacteria and $S$. cerevisiae yeast to $\gamma$-radiation was significantly increased in the bicarbonate buffer. That was due to the formation of carbonate radical in the reaction of $\mathrm{HCO}_{3}{ }^{-}$with products of water photolysis [12]. Our results suggest that the enhanced cytotoxic action of $\mathrm{H}_{2} \mathrm{O}_{2}$ and $\mathrm{Fe}^{2+}$ in the presence of bicarbonate ions can be associated with the intracellular generation of carboxyl radical, because there is no information regarding direct non-enzymatic reaction between $\mathrm{HCO}_{3}^{-}$and $\mathrm{H}_{2} \mathrm{O}_{2}$ or iron ions [11]. It was assumed that bicarbonate ions can enter yeast cells through mammalian Slc4-like proteins which were also indentified in yeast as bicarbonate transporters [21]. In cells, $\mathrm{HCO}_{3}{ }^{-}$can enhance $\mathrm{H}_{2} \mathrm{O}_{2}$-scavenging activity of $\mathrm{Cu}, \mathrm{Zn}-\mathrm{SOD}$, as it was shown in vitro [15]. Thus, $\mathrm{CO}_{3}{ }^{--}$can be produced in this reaction. $\mathrm{CO}_{3}{ }^{--}$is more reactive compound than $\mathrm{H}_{2} \mathrm{O}_{2}$, and this fact can explain a higher sensitivity of yeast cells to hydrogen peroxide in the presence of bicarbonate ions. The enhanced sensitivity of $S$. cerevisiae to ferrous sulfate treatment in the presence of bicarbonate (Fig. 1, B) can also be explained by $\mathrm{CO}_{3}{ }^{--}$formation. It is known, the toxicity of $\mathrm{Fe}^{2+}$ is connected with its ability to generate hydroxyl radical in Fenton reaction [24]. In turn, hydroxyl radical can react with $\mathrm{HCO}_{3}{ }^{-} / \mathrm{CO}_{3}{ }^{2-}$ to form $\mathrm{CO}_{3}{ }^{--}[3,16,20]$. Despite $\mathrm{CO}_{3}{ }^{--}$is less reactive compound than $\cdot \mathrm{OH}, \mathrm{CO}_{3}{ }^{--}$has a much longer half-life and can therefore diffuse further and oxidatively modify distant cellular targets [16].
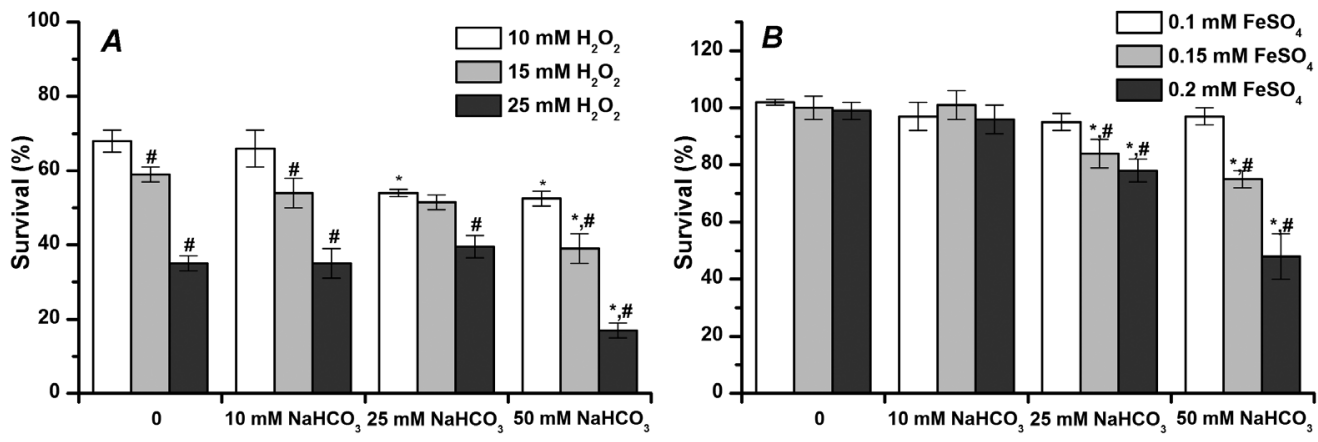

Fig. 1. Survival of $S$. cerevisiae $\mathrm{YPH} 250$ cells treated with $\mathrm{H}_{2} \mathrm{O}_{2}(A)$ or $\mathrm{FeSO}_{4}(B)$ for $2 \mathrm{~h}$ in the presence of $\mathrm{NaHCO}_{3}{ }^{*}$ - significant different from respective values of the group without $\mathrm{NaHCO}_{3},{ }^{*}-$ from respective values of the group treated with $10 \mathrm{mM} \mathrm{H}_{2} \mathrm{O}_{2}(A)$ or with $0.1 \mathrm{mM} \mathrm{FeSO}_{4}(B)$ with $P<0.05$ using Dunnett's test, $n=4-6$

Рис. 1. Виживання клітин S. cerevisiae YPH250 після двогодинної інкубації з $\mathrm{H}_{2} \mathrm{O}_{2}(A)$ та $\mathrm{FeSO}_{4}(B)$ за наявності $\mathrm{NaHCO}_{3}$. ${ }^{*}$ - вірогідно відрізняється від відповідних значень у пробах без $\mathrm{NaHCO}_{3}$,

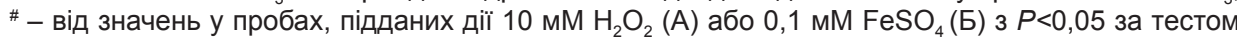
Даннетта, $\mathrm{n}=4-6$

Since the ability of bicarbonate ions to potentiate toxicity of hydrogen peroxide and iron ions could be connected with the intensification of free radical processes, the levels of oxidative stress markers such as protein carbonyl groups and glutathione were measured in yeast cells. Content of carbonyl group in proteins $(\mathrm{CP})$ is a widely used parameter of oxidative damages of proteins $[9,17,22]$. Glutathione $(\mathrm{GSH})$ is a low molecular mass antioxidant which plays an important role in the maintenance of redox homeostasis in S. cerevisiae [25]. CP levels and levels of oxidized glutathione (GSSG) were similar control cells and in cells treated $0.2 \mathrm{mM} \mathrm{FeSO}_{4}$ in the absence or presence of 
$\mathrm{NaHCO}_{3}$ (see Table). At the same time, total GSH was decreased in cells treated with $0.2 \mathrm{mM} \mathrm{FeSO}_{4}$ in the presence of $\mathrm{NaHCO}_{3}$ at higher concentrations. Accordingly, the total GSH was $22 \%$ lower in cells treated with $0.2 \mathrm{mM} \mathrm{FeSO}_{4}$ and $50 \mathrm{mM} \mathrm{NaHCO}_{3}$.

Similar results were obtained when the ability of bicarbonate to modulate sensitivity of yeast cells to menadione was studied [17]. Bicarbonate enhanced cytotoxicity of menadione that was accompanied by decreased GSH level in cells without changes in $\mathrm{CP}$ levels. The absence of changes in $\mathrm{CP}$ level could suggest that $\mathrm{CO}_{3}{ }^{--}$generated in bicarbonate buffer might promote other types of protein damages which are different from carbonylation. For example, $\mathrm{CO}_{3}{ }^{--}$was found can form tyrosyl radical and tyrosine cross-links and oxidize SH-groups of cysteine $[1,6,26] . \mathrm{CO}_{3}{ }^{--}$can also damage DNA by reacting with guanine base producing 8-oxoguanine [27]. The decrease in level of GSH which is a cysteine-containing tripeptide seems not to be connected with its oxidation because the level of GSSG was unchanged in cells co-treated with ferrous sulfate and $\mathrm{NaHCO}_{3}$ (See Table). Obviously, the synthesis GSH de novo can be decreased under these conditions. The decreased GSH level can lead to disturbing redox balance in cells and reduce antioxidant defense. It could enhance yeast sensitivity to oxidative stress inductors in bicarbonate buffer.

Level of glutathione and carbonyl proteins in S. cerevisiae YPH250 cells treated with $\mathrm{FeSO}_{4}$ in the presence of $\mathrm{NaHCO}_{3}(\mathrm{M} \pm \mathrm{m}, \mathrm{n}=4-5)$

Вміст глутатіону та карбонільних груп білків у клітинах S. cerevisiae YPH250, проінкубованих $3 \mathrm{FeSO}_{4}$ за наявності $\mathrm{NaHCO}_{3}(\mathrm{M} \pm \mathrm{m}, \mathrm{n}=4-5)$

\begin{tabular}{|c|c|c|c|c|c|}
\hline \multirow{2}{*}{ Conditions } & \multirow{2}{*}{ Parameter } & \multicolumn{4}{|c|}{$\mathrm{NaHCO}_{3}, \mathrm{mM}$} \\
\hline & & 0 & 10 & 25 & 50 \\
\hline \multirow{3}{*}{ Control } & $\begin{array}{l}\text { Total GSH, } \mu \mathrm{M} / \\
\mathrm{OD}_{600}\end{array}$ & $2.61 \pm 0.04$ & $2.51 \pm 0.12$ & $2.36 \pm 0.17$ & $2.25 \pm 0.14$ \\
\hline & GSSG, $\mu \mathrm{M} / \mathrm{OD}_{600}$ & $0.626 \pm 0.049$ & $0.642 \pm 0.112$ & $0.526 \pm 0.064$ & $0.611 \pm 0.052$ \\
\hline & $\mathrm{CP}, \mathrm{nmol} / \mathrm{mg}$ protein & $3.93 \pm 0.21$ & $4.04 \pm 0.25$ & $3.86 \pm 0.61$ & $3.65 \pm 0.16$ \\
\hline \multirow{3}{*}{$0.2 \mathrm{mM} \mathrm{FeSO}_{4}$} & $\begin{array}{l}\text { Total GSH, } \\
\mu \mathrm{M} / \mathrm{OD}_{600}\end{array}$ & $2.74 \pm 0.04$ & $2.36 \pm 0.19$ & $2.28 \pm 0.05^{*}$ & $2.13 \pm 0.18^{*}$ \\
\hline & GSSG, $\mu \mathrm{M} / \mathrm{OD}_{600}$ & $0.655 \pm 0.034$ & $0.660 \pm 0.075$ & $0.601 \pm 0.041$ & $0.580 \pm 0.045$ \\
\hline & $\mathrm{CP}, \mathrm{nmol} / \mathrm{mg}$ protein & $4.17 \pm 0.29$ & $3.84 \pm 0.25$ & $4.15 \pm 0.17$ & $3.86 \pm 0.28$ \\
\hline
\end{tabular}

Comment: "Significantly different from respective values of the group without $\mathrm{NaHCO}_{3}$ with $P<0.05$ using Dunnett's test

Примітка: 'Вірогідно відрізняється від відповідного значення у пробах без $\mathrm{NaHCO}_{3}$ з $P<0,05$ за тестом Даннетта

In next step of experiments, the survival of yeast cells treated with mixture of " $2 \mathrm{mM}$ $\mathrm{H}_{2} \mathrm{O}_{2}+2 \mathrm{mM} \mathrm{FeSO}_{4}$ " was studied. Hydroxyl radicals are directly generated in this mixture. The survival of $\mathrm{YPH} 250$ cells treated with " $\mathrm{Fe}^{2+} / \mathrm{H}_{2} \mathrm{O}_{2}$ " in $50 \mathrm{mM} \mathrm{KPi}(\mathrm{pH} 7.5)$ or in $50 \mathrm{mM}$ sodium bicarbonate buffer ( $\mathrm{pH} \mathrm{7.5)} \mathrm{was} \mathrm{calculated} \mathrm{(Fig.} \mathrm{2).} \mathrm{The} \mathrm{number} \mathrm{of} \mathrm{the}$ viable cells was significantly decreased in both buffers but the cells treated in sodium bicarbonate buffer were more resistant to " $\mathrm{Fe}^{2+} / \mathrm{H}_{2} \mathrm{O}_{2}$ " with 1.6-fold higher survival compared to the one in $\mathrm{KPi}$. The results suggest that bicarbonate can alleviate toxic action of $\mathrm{Fe}^{2+} / \mathrm{H}_{2} \mathrm{O}_{2}$ system. Given that $\mathrm{HCO}_{3}{ }^{-}$can react with ${ }^{\circ} \mathrm{OH}$ forming $\mathrm{CO}_{3}{ }^{-}$, it can be supposed, that $\mathrm{CO}_{3}{ }^{-}$is less toxic, than ${ }^{\circ} \mathrm{OH}$, and therefore cells survived better. At the same time, the experiments above showed that bicarbonate enhanced toxicity of $\mathrm{H}_{2} \mathrm{O}_{2}$ and

ISSN 1996-4536 (print) • ISSN 2311-0783 (on-line) • Біологічні Студії / Studia Biologica • 2016 • Том 10/№2 • С. 53-62 
$\mathrm{Fe}^{2+}$ if yeast cells were treated with these compounds separately. Similar results were observed previously on E. coli та $S$. cerevisiae exposed to radiolysis products [12]. Yeast and bacteria were more sensitive to $\mathrm{CO}_{3}{ }^{--}$, than to ${ }^{\circ} \mathrm{OH}$, but under the combined treatment with these radicals cells survived better than in the medium where ${ }^{\circ} \mathrm{OH}$ was only generated. The protective effects of bicarbonate were increased when high amounts of $\mathrm{OH}$ were produced [12]. The authors explained these results by complicated kinetics of an interaction between $\mathrm{HCO}_{3}{ }^{-} / \mathrm{CO}_{3}{ }^{2-}, \mathrm{CO}_{3}{ }^{--}$and ${ }^{\circ} \mathrm{OH}$. It can be supposed, if ${ }^{\circ} \mathrm{OH}$ and $\mathrm{CO}_{3}{ }^{--}$are produced in relatively moderate amounts, the combination of these radicals enhances their toxic action. When ${ }^{\circ} \mathrm{OH}$ is produced in high concentrations, it is more dangerous than $\mathrm{CO}_{3}{ }^{--}$due to very short life time. Under treatment with system " $\mathrm{Fe}^{2+} / \mathrm{H}_{2} \mathrm{O}_{2}$ " in bicarbonate buffer, most ${ }^{\circ} \mathrm{OH}$ produced can rapidly react with bicarbonate ions with formations of large amounts of radical $\mathrm{CO}_{3}{ }^{--}$. On the other hand, at high amounts, $\mathrm{CO}_{3}{ }^{--}$can react with each other to form non-radical ions: $\mathrm{CO}_{3}{ }^{-{ }^{-}}+\mathrm{CO}_{3}{ }^{--} \rightarrow$ $\mathrm{CO}_{2}+\mathrm{CO}_{4}{ }^{2-}$ [3]. This can explain a decreased toxicity of " $\mathrm{Fe}^{2+} / \mathrm{H}_{2} \mathrm{O}_{2}$ " in bicarbonate buffer, but not in KPi. When yeast cells were exposed to $\mathrm{Fe}^{2+}$ and $\mathrm{H}_{2} \mathrm{O}_{2}$ separately, it seems that production of ${ }^{\circ} \mathrm{OH}$ was lower, therefore, toxicity of $\mathrm{CO}_{3}{ }^{-{ }^{-}}$was more expressed and yeast viability was reduced.

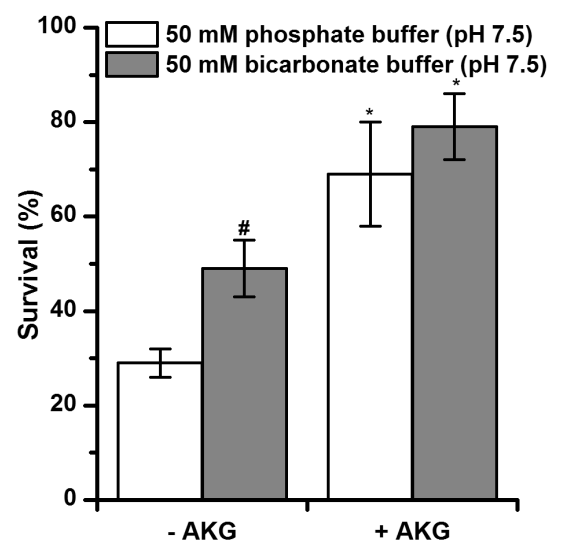

Fig. 2. Survival of $\mathrm{S}$. cerevisiae $\mathrm{YPH} 250$ cells treated with "2 $\mathrm{mM} \mathrm{H}_{2} \mathrm{O}_{2}+2 \mathrm{mM} \mathrm{FeSO}_{4}$ " for $1 \mathrm{~h}$ in $50 \mathrm{mM}$ potassium phosphate buffer ( $\mathrm{pH} 7.5)$ or $50 \mathrm{mM}$ sodium bicarbonate buffer ( $\mathrm{pH} 7.5$ ) without or with $10 \mathrm{mM}$ AKG. * - significant different from respective values of the group without AKG, * - from respective values in KPi with $P<0.05$ using Student's t-test, $\mathrm{n}=5-6$

Рис. 2. Виживання клітин S. cerevisiae YPH250 після інкубації протягом 1 год у системі «2 $\mathrm{MM} \mathrm{H}_{2} \mathrm{O}_{2}+2 \mathrm{MM}$ $\mathrm{FeSO}_{4}$ » у 50 мМ калій-фоссратному $(\mathrm{pH} \mathrm{7,5)} \mathrm{або}$ 50 мМ натрій-бікарбонатному буфері $(\mathrm{pH} \mathrm{7,5)} \mathrm{без}$ та з додаванням 10 мМ АКГ. * - вірогідно відрізняється від відповідних значень у пробах без АКГ, \# - від відповідних значень проб у КФБ з $P<0,05$ за тестом Стьюдента, $\mathrm{n}=5-6$

Since pro-oxidant and protective effects of bicarbonate ions could depend on the intensity of ${ }^{\circ} \mathrm{OH}$ production, the ability of antioxidant compounds to modulate these bicarbonate activities was studied. Alpha-keroglutarate, an important intermediate of the Krebs cycle, was chosen as an antioxidant. In our previous works, the powerful $\mathrm{H}_{2} \mathrm{O}_{2}-$ scavenging in vitro activity of AKG was demonstrated [4]. As seen from Fig. 2, the addition of $10 \mathrm{mM} \mathrm{AKГ} \mathrm{enhanced} \mathrm{yeast} \mathrm{survival} \mathrm{in} \mathrm{system} \mathrm{"2} \mathrm{mM} \mathrm{H}_{2} \mathrm{O}_{2}+2 \mathrm{mM} \mathrm{FeSO}_{4}$ " in both KPi and bicarbonate buffers. The protective effects of AKG can be attributed its ability to non-enzymatically react with $\mathrm{H}_{2} \mathrm{O}_{2}$ and to prevent $\mathrm{OH}$ production [4]. The protective effect of AKG was more expressed in KPi buffer (cell survival increased from 29 to $68 \%$ ), than in sodium bicarbonate buffer (cell survival increased from 49 to $79 \%$ ). Thus, the presence of antioxidant compounds interferes partly with protective effects of bicarbonate ions. 


\section{CONCLUSIONS}

The obtained results suggest that bicarbonate ions at physiological concentrations (25-50 mM) can enhance and alleviate the toxic effects of hydrogen peroxide and iron ions on yeast $S$. cerevisiae. Both effects are likely to be caused by the formation of carbonate radicals. The level of ROS produced and their complicated interaction with bicarbonate ions seems to determine the direction of bicarbonate action. Bicarbonate ions sensitize yeast cells to the oxidants when ${ }^{\circ} \mathrm{OH}$ is produced in relatively low levels. When $\cdot \mathrm{OH}$ is produced in high amounts, the protective effects of bicarbonate can be observed. Alpha-ketoglutarate protects yeast cells under exposure in system " $\mathrm{Fe}^{2+} / \mathrm{H}_{2} \mathrm{O}_{2}$ " in $\mathrm{KPi}$ and bicarbonate buffers, although the protective effect is lower in bicarbonate buffer. Thus, $\mathrm{HCO}_{3}{ }^{-}$and $\mathrm{CO}_{3}{ }^{2-}$ ions which are widely distributed in biological systems, can show both prooxidant and antioxidant properties. The latter depend largely on the intensity of ROS production and the activity of other antioxidant compounds. The redox-activity of $\mathrm{CO}_{2}$, $\mathrm{HCO}_{3}{ }^{-}$and $\mathrm{CO}_{3}{ }^{2-}$ ions suggests that the main physiological buffer can modulate oxidative injuries resulting from ROS generated endogenously in vivo under physiological or pathological conditions. For example, carbon dioxide retention due to hypoventilation resulting from airway obstruction, emphysema, respiratory muscle paralysis and pulmonary fibrosis increases bicarbonate-carbon dioxide levels above the physiological ones and this may be relevant to the oxidative damage associated with these clinical conditions. Even at physiological levels, the bicarbonate-carbon dioxide pair stimulates oxidations mediated by $\mathrm{Cu}, \mathrm{Zn}-\mathrm{SOD}$, hydrogen peroxide or iron ions. Thus, the study of the oxidants derived from the bicarbonate-carbon dioxide pair is likely to provide new mechanistic insights into the understanding and control of numerous pathological states.

\section{ACKNOWLEDGEMENTS}

The author is grateful to Dr. Y. Inoue for providing S. cerevisiae strain, Prof. Volodymyr I. Lushchak for financial support of the work, and Dr. Dmytro Gospodaryov for English editing. The work was supported by a grant of State Fund for Fundamental Research of Ukraine (\# F18/280-2007) to Volodymyr I. Lushchak.

1. Andrekopoulos C., Zhang H., Joseph J. et al. Bicarbonate enhances a-synuclein oligomerization and nitration: intermediacy of carbonate radical anion and nitrogen dioxide radical. Biochemical Journal, 2004; 378: 435-447.

2. Arai H., Berlett B.S., Chock, P.B. et al. Effect of bicarbonate on iron-mediated oxidation of low-density lipoprotein. PNAS, 2005; 102(30): 10472-10477.

3. Augusto O., Bonini M.G., Amanso A.M. et al. Nitrogen dioxide and carbonate radical anion: two emerging radicals in biology. Free Radical Biology and Medicine, 2002; 32(9): 841-859.

4. Bayliak M.M., Lylyk M.P., Vytvytska O.M. et al. Assessment of antioxidant properties of alphaketo acids in vitro and in vivo. European Food Research and Technology, 2016; 242(2): 179-188.

5. Berlett B.S., Chock P.B., Yim M.B. et al. Manganese(II) catalyzes the bicarbonate-dependent oxidation of amino acids by hydrogen peroxide and the amino acid-facilitated dismutation of hydrogen peroxide. PNAS, 1990; 87: 389-393.

6. Bonini M.G., Fernandes D.C., Augusto O. Albumin oxidation to diverse radicals by the peroxidase activity of $\mathrm{Cu}, \mathrm{Zn}$-superoxide dismutase in the presence of bicarbonate or nitrite: diffusible radicals produce cysteinyl and solvent-exposed and -unexposed tyrosyl radicals. Biochemistry, 2004; 43: 344-351.

ISSN 1996-4536 (print) • ISSN 2311-0783 (on-line) • Біологічні Студії / Studia Biologica • 2016 • Том 10/№2 • С. 53-62 
7. Bradford M.M. A rapid and sensitive method for the quantification of microgram quantities of protein utilizing the principle of protein-dye binding. Analytical Biochemistry, 1976; 72: 289-292.

8. Brooks S.P. A simple computer program with statistical tests for the analysis of enzyme kinetics. BioTechniques, 1992; 72: P. 906-911.

9. Davies M.J. Protein oxidation and peroxidation. Biochemical Journal, 2016; 473(7): 805-825.

10. Elam J.S., Malek K., Rodriguez J.A. et al. An alternative mechanism of bicarbonate-mediated peroxidation by copper-zinc superoxide dismutase: rates enhanced via proposed enzymeassociated peroxycarbonate intermediate. Journal of Biological Chemistry, 2003; 278(23): 21032-21039.

11. Jansson P.J., Del Castillo U., Lindqvist C. et al. Effects of iron on vitamin C/copper-induced hydroxyl radical generation in bicarbonate-rich water. Free Radical Research, 2005; 39 (5): 565-570.

12. King D.A., Sheafor M.W., Hurst J.K. Comparative toxicities of putative phagocyte-generated oxidizing radicals toward a bacterium (Escherichia coli) and a yeast (Saccharomyces cerevisiae). Free Radical Biology and Medicine, 2006; 41(5): 765-774.

13. Levine R.L., Wehr N., Williams J.A. et al. Determination of carbonyl groups in oxidized proteins. Methods in Molecular Biology, 2000; 99: 15-24.

14. Liochev S.I., Fridovich I. Carbon dioxide mediates Mn(II)-catalyzed decomposition of hydrogen peroxide and peroxidation reactions. Proceedings of the National Academy of Sciences (USA), 2004; 101: 12485-12490.

15. Liochev S.I., Fridovich I. Mechanism of the peroxidase activity of $\mathrm{Cu}, \mathrm{Zn}$ superoxide dismutase. Free Radical Biology and Medicine, 2010; 48(12): 1565-1569.

16. Luc R., Vergely C. Forgotten radicals in biology. International Journal of Biomedical Science: IJBS, 2008; 4(4): 255-259.

17. Lushchak O.V., Bayliak M.M., Korobova O.V. et al. Buffer modulation of menadione-induced oxidative stress in Saccharomyces cerevisiae. Redox Reports, 2009; 14: 214-220.

18. Lushchak V., Lushchak L., Mota A. et al. Oxidative stress and antioxidant defences in goldfish Carassius auratus during anoxia and reoxygenation. American Journal of Physiology, 2001; 280: R100-R107.

19. Lushchak V.I. Free radicals, reactive oxygen species, oxidative stress and its classification. Chemico-Biological Interactions, 2014, 224C: 164-175.

20. Medinas D.B., Cerchiaro G., Trindade D.F. et al. The carbonate radical and related oxidants derived from bicarbonate buffer. IUBMB Life, 2007; 59: 255-262.

21. Parker M.D., Boron W.F. The divergence, actions, roles, and relatives of sodium-coupled bicarbonate transporters. Physiological Research, 2013; 93(2): 803-959.

22. Prokopiv T.M., Fedorovych D.V., Boretsky Y.R. et al. Oversynthesis of riboflavin in the yeast Pichia guilliermondii is accompanied by reduced catalase and superoxide dismutases activities. Current Microbiology, 2013; 66(1): 79-87.

23. Queliconi B.B., Marazzi T.B., Vaz S.M. et al. Bicarbonate modulates oxidative and functional damage in ischemia-reperfusion. Free Radical Biology and Medicine, 2013; 55:46-53.

24. Stadtman E.R., Levine R.L. Free radical-mediated oxidation of free amino acids and amino acid residues in proteins. Amino Acids, 2003; 25(3-4): 207-218.

25. Toledano M.B., Delaunay-Moisan A., Outten C.E. et al. Functions and cellular compartmentation of the thioredoxin and glutathione pathways in yeast. Antioxidants and Redox Signaling Journal, 2013; 18(13): 1699-711.

26. Vesela A., Milhelm J. The role of carbon dioxide in free radical reactions of the organism. Physiological Research, 2002; 51: 335-339.

27. Yadav A., Mishra P.C. Carbonate radical anion as an efficient reactive oxygen species: Its reaction with guanyl radical and formation of 8-oxoguanine Chemical Physics, 2012; 405: 76-88.

28. Zhang H., Joseph J., Gurney M. et al. Bicarbonate enhances peroxidase activity of Cu,Znsuperoxide dismutase. Role of carbonate anion radical and scavenging of carbonate anion radical by metalloporphyrin antioxidant enzyme mimetics. Journal of Biological Chemistry, 2002; 277: 1013-1020.

ISSN 1996-4536 (print) • ISSN 2311-0783 (on-line) • Біологічні Студії / Studia Biologica • 2016 • Том 10/№2 • С. 53-62 


\section{ВПЛИВ БІКАРБОНАТІВ І АЛЬФА-КЕТОГЛУТАРАТУ НА ЧУТЛИВІСТЬ ДРІЖДЖІВ SACCHАROMYCES CEREVISIAE ДО ДIÏ ПЕРОКСИДУ ВОДНЮ ТА ІОНІВ 3АЛІЗА}

\section{М. М. Байляк}

Прикарпатський національний університет ім. Василя Стефраника вул. Шевченка, 57, Івано-Франківськ 76018, Україна e-mail: bayliak@ukr.net

Досліджено вплив бікарбонату натрію на чутливість дріжджів Saccharomyces cerevisiae до пероксиду водню та сульфату заліза. Життєздатність дріжджів, підданих дії 10-25 мM H $\mathrm{O}_{2}$ та 0,1-0,2 $\mathrm{MM} \mathrm{FeSO}_{4}$, значно знижувалася за додавання у середовище інкубації 25 або $50 \mathrm{mM} \mathrm{NaHCO}_{3}$. За обробки 0,2 мM FeSO 4 без бікарбонатів вміст у клітинах маркерів оксидативного стресу, а саме білкових карбонільних груп, загального й окисленого глутатіону не відрізнявся від відповідних показників у контролі (без $\mathrm{FeSO}_{4}$ та $\mathrm{NaHCO}_{3}$ ). У клітинах дріжджів, інкубованих з 0,2 мМ $\mathrm{FeSO}_{4}$ та 50 мM NaHCO , вміст загального глутатіону був нижчим завдяки зниженню його синтезу, а вміст карбонільних груп у білках і вміст окисленого глутатіону не відрізнявся від відповідних показників у клітин, які піддавалися дії $\mathrm{FeSO}_{4}$ без бікарбонатів. Клітини дріжджів, піддані дії суміші "2 мM $\mathrm{H}_{2} \mathrm{O}_{2}+2$ мM FeSO " у 50 мM натрій-бікарбонатному буфері виживали краще, ніж клітини, оброблені даними оксидантами у 50 мМ калій-фросфратному буфері. Додавання 10 мМ альфра-кетоглутарату підвищувало виживання клітин, оброблених у системі " $\mathrm{Fe}^{2+} / \mathrm{H}_{2} \mathrm{O}_{2}$ ", в обох буферах. Захисний ефект альфа-кетоглутарату, очевидно, пов'язаний з його здатністю знешкоджувати $\mathrm{H}_{2} \mathrm{O}_{2}$. Отримані результати свідчать про те, що бікарбонатні іони можуть як посилювати, так і послаблювати токсичну дію редокс-активних сполук на клітини S. cerevisiae. Ймовірно, що про-/антиоксидантна дія бікарбонатів залежить від кінетики взаємодії $\mathrm{HCO}_{3}{ }^{-}$з АФК, які утворюються під час дії оксидантів.

Ключові слова: Saccharomyces cerevisiae, альфа-кетоглутарат, бікарбонатіони, карбонатний радикал, оксидативний стрес.

\section{ВЛИЯНИЕ БИКАРБОНАТОВ И АЛЬФА-КЕТОГЛУТАРАТА НА ЧУВСТВИТЕЛЬНОСТЬ ДРОЖЖЕЙ SACCHAROMYCES CEREVISIAE К ПЕРЕКЕСИ ВОДОРОДА И ИОНАМ ЖЕЛЕЗА}

\section{М.М. Байляк}

Прикарпатский национальный университет им. Василия Стеффаника ул. Шевченко, 57, Ивано-Франковск 76018, Украина e-mail: bayliak@ukr.net

Исследовано влияние бикарбоната натрия на чувствительность дрожжей Saccharomyces cerevisiae к перекиси водорода и сульфата железа. Жизнеспособность дрожжей, обработанных 10-25 мM $\mathrm{H}_{2} \mathrm{O}_{2}$ и 0,1-0,2 мM FeSO уменьшалась при добавлении в среду инкубации 25 или 50 мМ NaHCO . При обработке 0,2 мM FeSO 4 в отсутствие бикарбонатов, содержание в клетках маркеров окислительного стресса, а именно белковых карбонильных групп, общего и окисленного глутатиона не отличалось от соответствующих показателей в контрольных

ISSN 1996-4536 (print) • ISSN 2311-0783 (on-line) • Біологічні Студії / Studia Biologica • 2016 • Том 10/№2 • С. 53-62 
клетках (без $\mathrm{FeSO}_{4}$ и $\mathrm{NaHCO}_{3}$ ). В клетках дрожжей, инкубированных с 0,2 мМ $\mathrm{FeSO}_{4}$ и 50 мM NaHCO 3 , содержание общего глутатиона было ниже за счет снижения его синтеза, а содержание окисленного глутатиона и карбонильных групп в белках не отличалось от соответствующих показателей у клеток, которые подвергались воздействию $\mathrm{FeSO}_{4}$ без бикарбонатов. Клетки дрожжей, обработанные смесью "2 мM H $\mathrm{O}_{2}+2$ мM FeSO " в 50 мМ натрий-бикарбонатном буфере, выживали лучше, чем клетки, обработанные данными оксидантами в 50 мМ калий-фосфатном буфере. Добавление 10 мМ альфа-кетоглутарата повышало выживаемость клеток, обработанных в системе " $\mathrm{Fe}^{2+} / \mathrm{H}_{2} \mathrm{O}_{2}$ ", в обоих буферах. Защитный эффект альфа-кетоглутарата, очевидно, связан с его способностью обезвреживать $\mathrm{H}_{2} \mathrm{O}_{2}$. Полученные результаты свидетельствуют о том, что бикарбонатные ионы могут как усиливать, так и ослаблять токсическое действие редокс-активных соединений на клетки S. cerevisiae. Вероятно, что про-/антиоксидантное действие бикарбонатов зависит от кинетики взаимодействия $\mathrm{HCO}_{3}{ }^{-}$с АФК, которые образуются при воздействии оксидантов.

Ключевые слова: Saccharomyces cerevisiae, альфа-кетоглутарат, бикарбонат-ионы, карбонатный радикал, окислительный стресс.

Одержано: 12.07.2016

ISSN 1996-4536 (print) • ISSN 2311-0783 (on-line) • Біологічні Студії / Studia Biologica • 2016 • Том 10/№2 • С. 53-62 